\title{
Anti-Helicobacter pylori activity and immunostimulatory effect of extracts from Byrsonima crassa Nied. (Malpighiaceae) Cibele Bonacorsi ${ }^{1}$, Maria Stella G Raddi*1, Iracilda Z Carlos ${ }^{1}$, Miriam Sannomiya ${ }^{2}$ and Wagner Vilegas ${ }^{2}$
}

Address: ${ }^{1}$ Departamento de Análises Clínicas, Faculdade de Ciências Farmacêuticas, Universidade Estadual Paulista (UNESP), Rua Expedicionários do Brasil 1621, CEP14801-960, Araraquara, SP, Brazil and 2Departamento de Química Orgânica, Instituto de Química, Universidade Estadual Paulista (UNESP), Rua Franciso Degni s/n, CEP 14800-900, Araraquara, SP, Brazil

Email: Cibele Bonacorsi - bonac@terra.com.br; Maria Stella G Raddi* - raddims@fcfar.unesp.br; Iracilda Z Carlos - carlosiz@fcfar.unesp.br; Miriam Sannomiya - miriamsa@posgrad.iq.unesp.br; Wagner Vilegas - vilegasw@iq.unesp.br

* Corresponding author

Published: 16 January 2009

BMC Complementary and Alternative Medicine 2009, 9:2 doi:10.1 186/1472-6882-9-2
Received: 29 September 2008

Accepted: 16 January 2009

This article is available from: http://www.biomedcentral.com/I472-6882/9/2

(c) 2009 Bonacorsi et al; licensee BioMed Central Ltd.

This is an Open Access article distributed under the terms of the Creative Commons Attribution License (http://creativecommons.org/licenses/by/2.0), which permits unrestricted use, distribution, and reproduction in any medium, provided the original work is properly cited.

\begin{abstract}
Background: Several in vitro studies have looked at the effect of medicinal plant extracts against Helicobacter pylori ( $H$. pylori). Regardless of the popular use of Byrsonima crassa (B. crassa) as antiemetic, diuretic, febrifuge, to treat diarrhea, gastritis and ulcers, there is no data on its effects against $H$. pylori. In this study, we evaluated the anti- $H$. pylori of $B$. crassa leaves extracts and its effects on reactive oxygen/nitrogen intermediates induction by murine peritoneal macrophages.
\end{abstract}

Methods: The minimal inhibitory concentration (MIC) was determined by broth microdilution method and the production of hydrogen peroxide $\left(\mathrm{H}_{2} \mathrm{O}_{2}\right)$ and nitric oxide $(\mathrm{NO})$ by the horseradish peroxidase-dependent oxidation of phenol red and Griess reaction, respectively.

Results: The methanolic $(\mathrm{MeOH})$ and chloroformic $\left(\mathrm{CHCl}_{3}\right)$ extracts inhibit, in vitro, the growth of $\mathrm{H}$. pylori with MIC value of $1024 \mu \mathrm{g} / \mathrm{ml}$. The $\mathrm{MeOH}$ extract induced the production $\mathrm{H}_{2} \mathrm{O}_{2}$ and $\mathrm{NO}$, but $\mathrm{CHCl}_{3}$ extract only $\mathrm{NO}$.

Conclusion: Based in our results, $B$. crassa can be considered a source of compounds with anti$H$. pylori activity, but its use should be done with caution in treatment of the gastritis and peptic ulcers, since the reactive oxygen/nitrogen intermediates are involved in the pathogenesis of gastric mucosal injury induced by ulcerogenic agents and $H$. pylori infections.

\section{Background}

Helicobacter pylori (H. pylori) is a spiral-shaped bacterium that colonizes the stomach of the half of all people worldwide [1]. Once a person is infected, the organism can live in the stomach indefinitely and may not cause clinical illness. It is still not clear how $H$. pylori are transmitted or why some people infected with its bacteria become sick and others do not [2]. Studies have also shown an associ- ation between long-term infection with $H$. pylori and the development of gastric adenocarcinoma $[3,4]$.

Therapy for $H$. pylori infection consists of 1-2 weeks of one or two effective antibiotics, such as amoxicillin, tetracycline, metronidazole, or clarithromycin, plus either ranitidine bismuth citrate, bismuth subsalicylate, or a proton pump inhibitor [5]. Many clinical treatment trials involv- 
ing patients with $H$. pylori infection and gastric or duodenal ulcers show that curing the infection is associated with a marked reduction in ulcer recurrence rates [6]. However, eradication by the triple therapy is not always successful and the acquisition by $H$. pylori resistant to antibiotics could represent a serious problem that may reduce treatment efficacy [7]. Considering that eradication therapies can be ineffective and undesirable side effects may occur, the search for new drugs for the development of alternative therapies is very important [1]. Plant extracts are among the attractive sources of new drugs and have been shown to produce promising results in the treatment of gastric ulcers [8-11].

The genus Byrsonima, which is composed of approximately 150 species, belongs to the Malpighiaceae family and is widely distributed throughout tropical America $[12,13]$. This family is constituted by approximately 800 species distributed in 60 genera and about $50 \%$ of these species are concentrated in Brazil [14]. In traditional Brazilian medicine, Byrsonima crassa (B. crassa) is used as antiemetic, diuretic, febrifuge, to treat diarrhea, gastritis and ulcer [15].

The potential antiulcerogenic of $B$. crassa leaves extracts were demonstrated by Sannomiya et al. [16]. The results of this research showed that methanolic $(\mathrm{MeOH})$ extract provided better gastroprotective activity than chloroformic $\left(\mathrm{CHCl}_{3}\right)$ extract. The presence of amentoflavone, quercetin derivatives and catechins in the $\mathrm{MeOH}$ extract were suggested to contribute for the gastroprotective activity since these compounds were reported to inhibit lipid peroxidation as well as possess a very potent antioxidant activity $[16,17]$.

Several in vitro studies have looked at the effect of medicinal plant extracts against $H$. pylori [18-21]. This bacteria induces inflammation, infiltration and activation of immune cells, accumulation of reactive oxygen species, and oxidative DNA damage in the gastric mucosa [22-24]. The antimicrobial compounds from plants may inhibit bacterial growth by different mechanisms than those presently used antimicrobials, and could therefore be of clinical value in the treatment of resistant microbial strains, including $H$. pylori [25].

Despite of the popular use of $B$. crassa as a medicinal plant, there is no data on its antimicrobial activity and immunostimulatory effects. In this study, we evaluated, in vitro, the anti-H. pylori of $B$. crassa leaves extracts $(\mathrm{MeOH}$ and $\mathrm{CHCl}_{3}$ ) and its immunostimulatory effects in murine immune system by determination of oxygen $\left(\mathrm{H}_{2} \mathrm{O}_{2}\right)$ and nitrogen $(\mathrm{NO})$ intermediates reactive.

\section{Methods \\ Plant material}

B. crassa Nied. (Malpighiaceae) leaves were collected at Porto Nacional, Tocantins State, Brazil and authenticated by Prof. Eduardo Ribeiro dos Santos. A voucher specimen (Nr. 3377) was deposited at the Herbarium of the Tocantins University.

\section{Extraction and preparation of extract solutions}

The aerial parts (2.0 kg of leaves) obtained were dried (at $40^{\circ} \mathrm{C}$ for 4 days) and powdered. The dry powdered material was macerated three times with 2 liters of chloroform and methanol successively at room temperature and left for $48 \mathrm{~h}$ in the respective solvent. The solvents were filtered and evaporated at $60^{\circ} \mathrm{C}$ under reduced pressure providing $\mathrm{CHCl}_{3}(53.8 \mathrm{~g})$ and $\mathrm{MeOH}(158.3 \mathrm{~g})$ extracts. The yields $(\mathrm{w} / \mathrm{w})$ for the $\mathrm{CHCl}_{3}$ and $\mathrm{MeOH}$ extracts from the air-dried and powdered leaves of $B$. crass $a$ leaves were 2.7 and $7.9 \%$, respectively [16]. Stock solutions of plant extracts $(50 \mathrm{mg} / \mathrm{ml})$ were prepared in dimethyl sulfoxide (DMSO) and stored at $-20^{\circ} \mathrm{C}$. Dilutions of the stock solutions were made in Brain Heart Infusion (BHI) plus 10\% fetal bovine serum (FBS) for antimicrobial activity and in potassium phosphate buffer or RPMI-1640 medium for measurement of $\mathrm{H}_{2} \mathrm{O}_{2}$ and $\mathrm{NO}$ production by peritoneal macrophages. Fresh solutions were prepared for each experiment.

\section{Bacterial strain}

H. pylori ATCC 43504, metronidazole resistant (MtzR) and amoxicillin susceptible (AmxS), was obtained from the American Type Culture Collection (Manassas, VA, USA). The bacterium was cultured in Columbia agar containing $5 \%$ sheep blood at $36-37^{\circ} \mathrm{C}$ for 3 days, in $5 \% \mathrm{O}_{2}$, $10 \% \mathrm{CO}_{2}, 85 \% \mathrm{~N}_{2}$ atmosphere.

\section{Antimicrobial activity}

The wells of a 96-well microplate were filled with $100 \mu \mathrm{l}$ of various concentrations of the extracts. Same volume of $H$. pylori suspension (about $10^{6} \mathrm{cfu} / \mathrm{ml}$ ) was added to each well. The absorbance was determined using an automatic ELISA microplate reader (Spectra \& Rainbow Readers, Tecan) adjusted at $620 \mathrm{~nm}$. The microplate was incubated at $36-37^{\circ} \mathrm{C}$ for 3 days, under microaerophilic atmosphere, agitated and the absorbance was read again in the reader at the same wavelength. The absorbencies were compared to the values obtained before incubation to detect an increase in bacterial growth. The lowest concentration of the test extract resulting in inhibition of bacterial growth, at least, more than $90 \%$, was taken as the minimal inhibitory concentration (MIC). Amoxicillin and metronidazole were used as reference antimicrobial. 


\section{Animals}

Experiments involving Swiss mice (6-8 weeks old, 18 to $25 \mathrm{~g}$ ) were performed in accordance with the regulations of Research Ethics Committee (01/2005), Faculty of Pharmaceutical Sciences, Unesp, São Paulo, Brazil.

\section{Peritoneal macrophages}

Resident and thioglycollate-elicited peritoneal exudate cells were obtained from mice following intraperitoneal injection of $3 \mathrm{ml}$ thioglycollate medium $(3.0 \mathrm{~g} / 100 \mathrm{ml})$ and lavage of the peritoneal cavity with $5 \mathrm{ml}$ of $10 \mathrm{mM}$ phosphate-buffered saline (PBS), $\mathrm{pH} 7.2,3-4$ days later. The proportion of macrophages in the peritoneal exudate was determined by cell staining with May-GruenwaldGiemsa. Cell preparations contained more than 95\% macrophages. The cells were washed twice with PBS and resuspended in appropriate medium for each test.

\section{Macrophages viability}

For the determination of the concentrations of extracts that do not cause cell death, the cytotoxic assay was performed as described. Macrophages $\left(10^{6}\right.$ cells $\left./ \mathrm{ml}\right)$ were suspended in RPMI-1640 containing 5\% heat-inactivated FBS, $100 \mathrm{IU} / \mathrm{ml}$ penicillin, $100 \mu \mathrm{g} / \mathrm{ml}$ streptomycin and $50 \mathrm{mM}$ 2-mercaptoethanol. The suspension $(100 \mu \mathrm{l})$ was added to each well of a 96-well microplate and the cells were incubated at $37^{\circ} \mathrm{C}$ in a humidified atmosphere containing $5 \% \mathrm{CO}_{2}$. After $1 \mathrm{~h}$, the wells were washed and adhering cells exposed to different concentrations of methanolic or chloroformic extract for 1 and $24 \mathrm{~h}$. The test was accompanied by a viability positive control (RPMI plus cells) and negative control (RPMI plus extract). Finally, neutral red (NR) assay [26] was performed and the absorbance at $540 \mathrm{~nm}$ (reference filter $620 \mathrm{~nm}$ ) determined using an automatic microplate reader.

\section{Measurement of $\mathrm{H}_{2} \mathrm{O}_{2}$}

Production $\mathrm{H}_{2} \mathrm{O}_{2}$ was measured by the horseradish peroxidase (HRP)-dependent oxidation of phenol red [27]. Macrophages $\left(2 \times 10^{6}\right.$ cells $\left./ \mathrm{ml}\right)$ were suspended in $10 \mathrm{mM}$ potassium phosphate buffer containing $140 \mathrm{mM} \mathrm{NaCl}$, $5.5 \mathrm{mM}$ dextrose, $0.56 \mathrm{mM}$ phenol red and $0.01 \mathrm{mg} / \mathrm{ml}$ HRP, pH 7.4. Briefly, $100 \mu \mathrm{l}$ of this suspension was added to each of a 96-well culture tissue plate and exposed to methanolic and chloroformic extracts (concentrations of extracts that do not cause cell death), for $1 \mathrm{~h}$ (time for the $\mathrm{H}_{2} \mathrm{O}_{2}$ assay) at $37^{\circ} \mathrm{C}$ in a $5 \% \mathrm{CO} 2$ atmosphere. The reaction was stopped by the addition of $10 \mu \mathrm{l}$ of $1 \mathrm{~N} \mathrm{NaOH}$ and the absorbances were read at $620 \mathrm{~nm}$ using a microplate reader. The results are reported as nmol $/ 2 \times 10^{5}$ cells. The experiment was accompanied by a positive control (buffer plus macrophages and $200 \mathrm{nM}$ phorbol myristate acetate, PMA) and negative control (buffer plus macrophages).

\section{Measurement of NO}

NO synthesis was determined by measuring the accumulation of nitrite, a stable metabolite of $\mathrm{NO}$, using the Griess reaction [28]. Macrophages $(100 \mu \mathrm{l})$ in at $5 \times 10^{6}$ cells/ml in RPMI containing 5\% heat-inactivated FBS, 100 $\mathrm{IU} / \mathrm{ml}$ penicillin, $100 \mu \mathrm{g} / \mathrm{ml}$ streptomycin and $50 \mathrm{mM} 2$ mercaptoethanol, were added to each well of a 96-well cell culture plate and exposed to methanolic and chloroformic extracts (concentrations that do not cause cell death), for $24 \mathrm{~h}$ (time for the NO assay) at $37^{\circ} \mathrm{C}$ in a $5 \%$ CO 2 atmosphere. After incubation, $50 \mu$ aliquots of culture supernatant were mixed with an equal volume of Griess reagent and incubated at room temperature for 10 min. Absorbance at $540 \mathrm{~nm}$ was measured using a microplate reader. The results are reported as $\mu \mathrm{mol} / 5 \times 10^{5}$ cells. Each experiment was accompanied by a positive control (RPMI plus macrophages and $10 \mu \mathrm{g} / \mathrm{ml}$ lipopolysaccharide, LPS) and a negative control (RPMI and macrophages).

\section{Statistical Analysis}

The results are expressed as means \pm SD (Standard Deviation). All tests were perform in triplicate and repeated at least three times. Statistical difference between groups was determined by one-way analysis of variance (ANOVA). A $p$-value $<0.05$ was considered statistically significant.

\section{Results}

The antibacterial activities of the extracts $(\mathrm{MeOH}$ and $\mathrm{CHCl}_{3}$ ) from $B$. crassa against $H$. pylori, using spectrophotometer microdilution assay, are showed in Figure 1. The results demonstrated that both $\mathrm{MeOH}$ and $\mathrm{CHCl}_{3}$ extract exhibited anti-H. pylory activity with MIC value of 1024 $\mu \mathrm{g} / \mathrm{ml}$. The data presented in Figure 2 summarize the release of $\mathrm{H}_{2} \mathrm{O}_{2}$ and $\mathrm{NO}$ by murine peritoneal macrophages. The MeOH extract at concentrations of $280 \mu \mathrm{g} / \mathrm{ml}$ (maximum concentration that did not cause cell death) was able to induce the release of $20.16 \pm 0.58 \mathrm{nmol} / 2 \times$ $10^{5}$ cells and $13.79 \pm 2.58 \mu \mathrm{mol} / 5 \times 10^{5}$ cells $\mathrm{H}_{2} \mathrm{O}_{2}$ and $\mathrm{NO}$, respectively. The $\mathrm{CHCl}_{3}$ extract at concentration of $200 \mu \mathrm{g} / \mathrm{ml}$ (maximum concentration that did not cause cell death) just induced the production of $\mathrm{NO}(8.63 \pm$ $0.35 \mu$ mols $/ 5 \times 10^{5}$ cells $)$.

\section{Discussion}

Many anti-H. pylori compounds exhibiting a significant inhibitory effect have been identified from plant materials, among them flavonoids, tannins, terpenes, aromatic aldehydes, alcohols, tannins and catechins [18,29-31]. Based on the popular use of $B$. crassa to treat gastritis and ulcer, we investigated, in vitro, the susceptibility of $H$. pylori ATCC 43504 (AmxS and MtzR strain) to MeOH and $\mathrm{CHCl}_{3}$ extracts obtained from the leaves of this medicinal plant. Both extracts presented MIC value of $1024 \mu \mathrm{g} / \mathrm{ml}$. In summary, our results suggest that $B$. crassa produces 
A

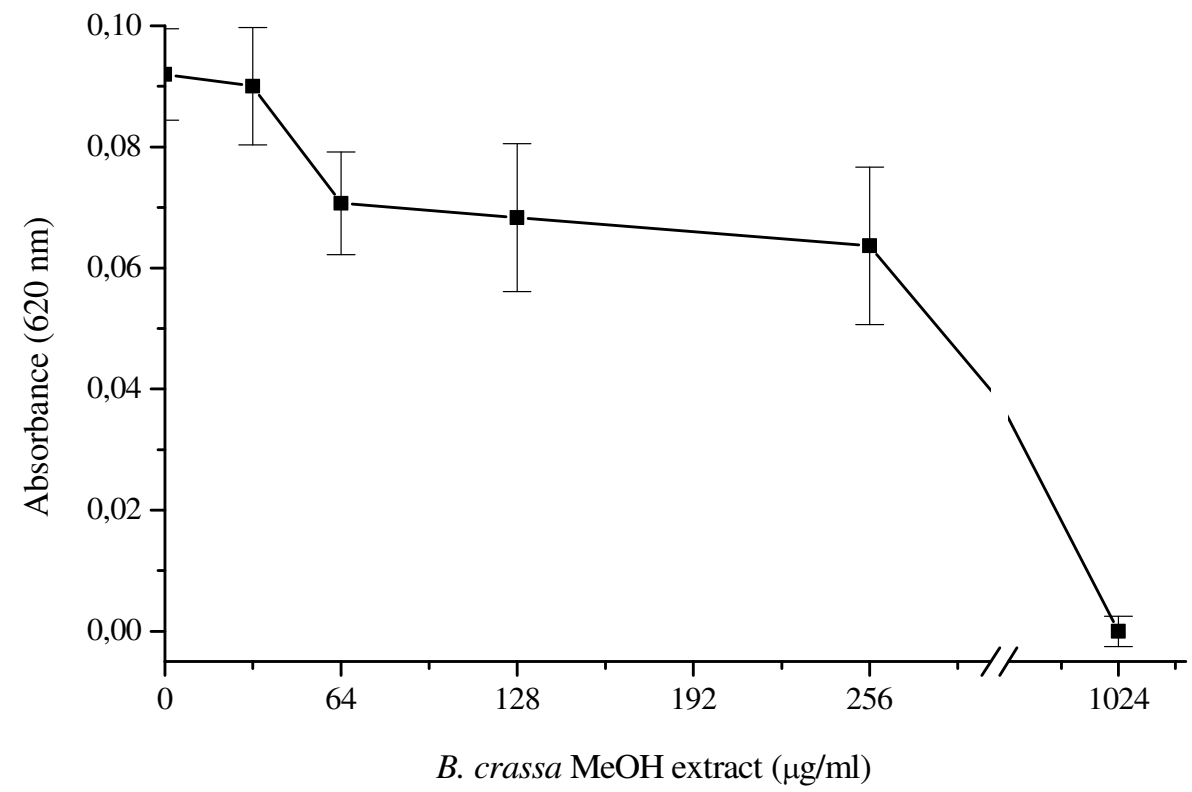

$\mathrm{B}$

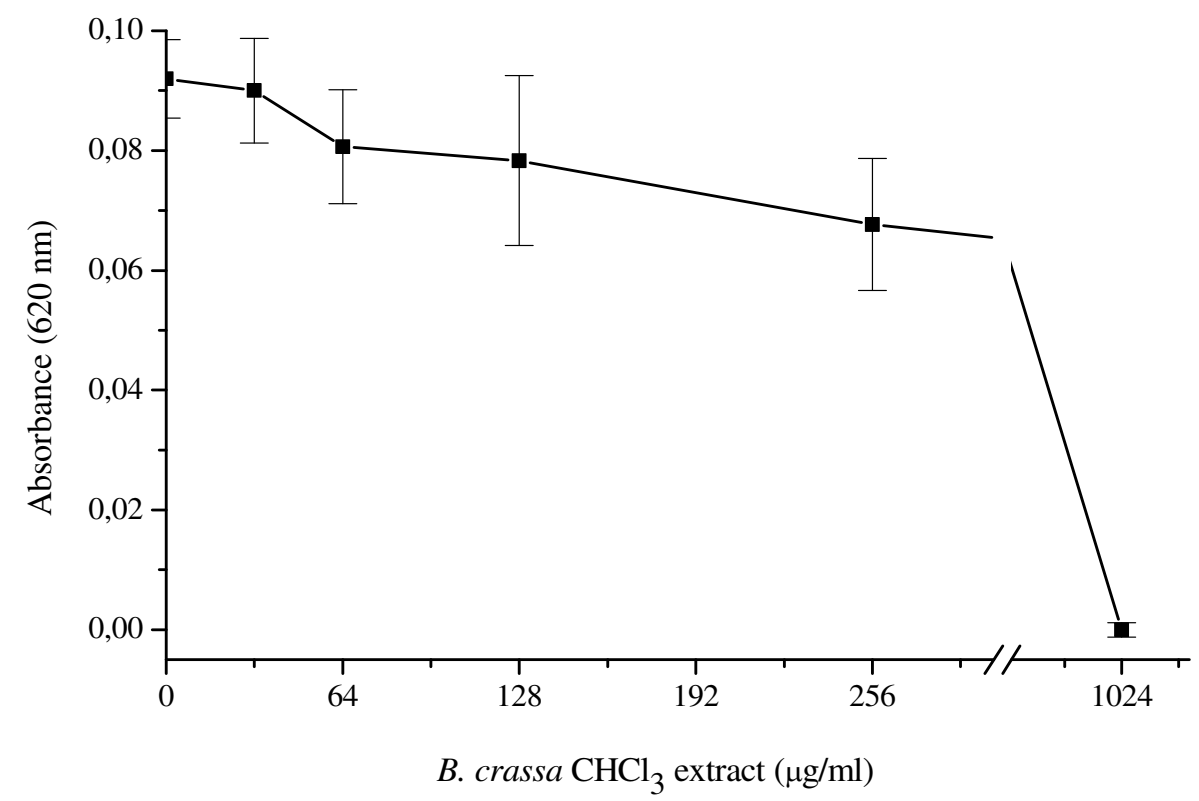

Figure I

Effect of the MeOH (A) and $\mathrm{CHCl}_{3}(\mathrm{~B})$ extracts obtained of Byrsonima crassa on growth of Helicobacter pylori, following incubation for $72 \mathrm{~h}$. 
A

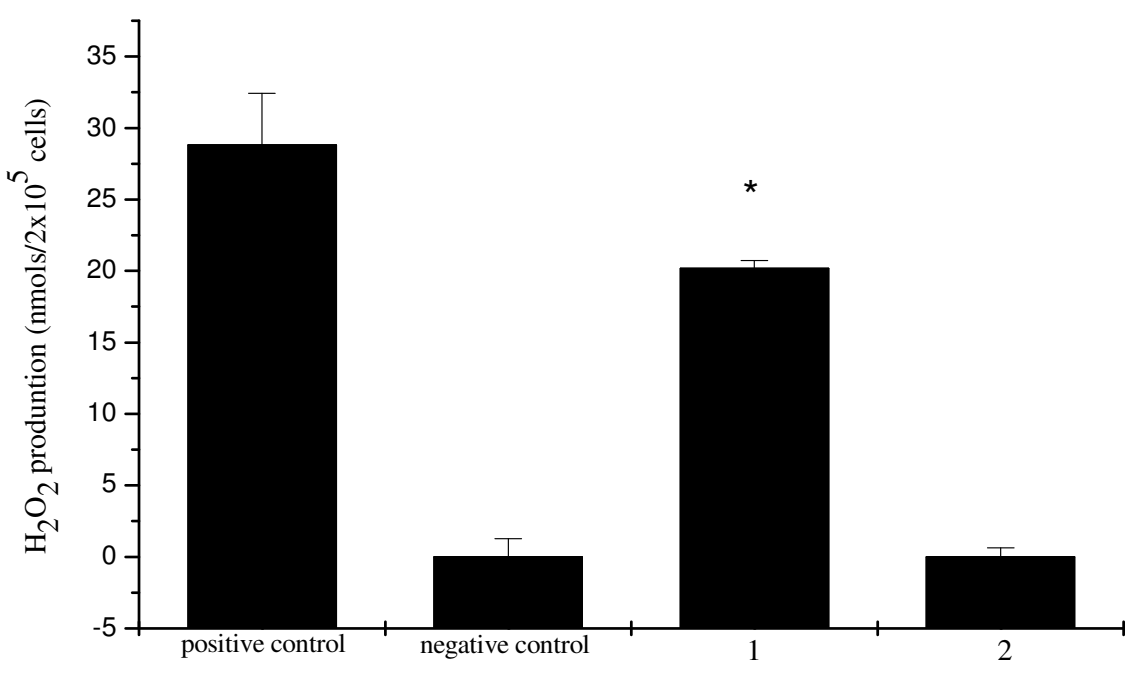

B. crassa extracts

B

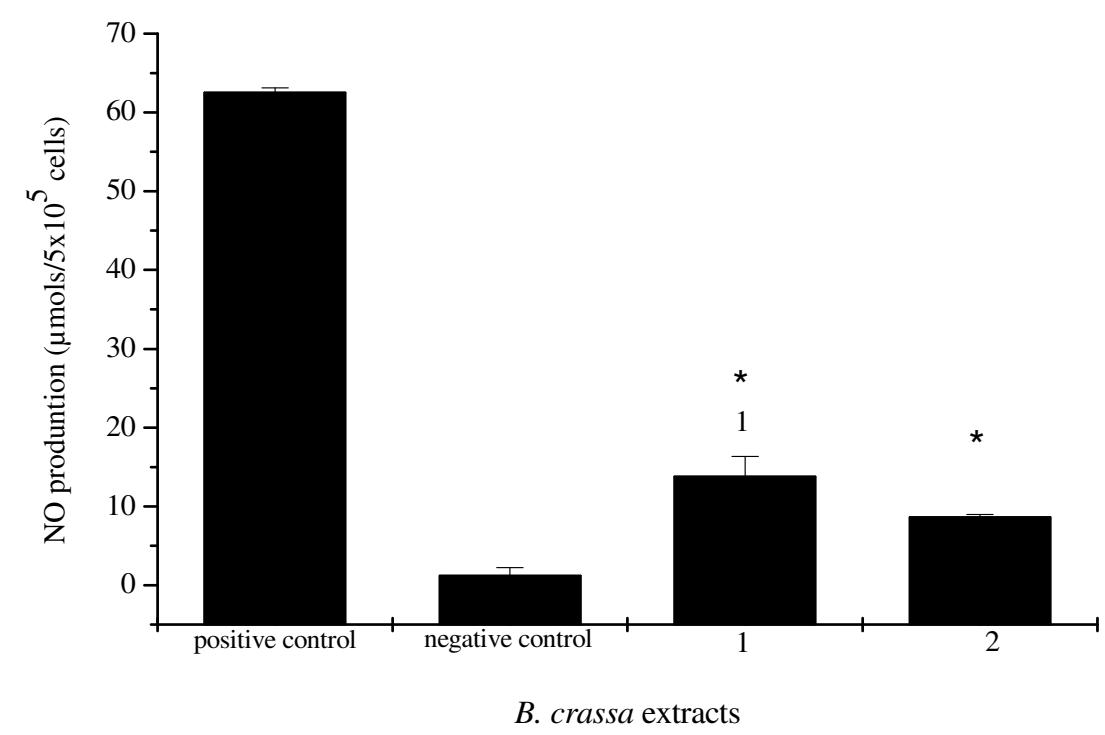

Figure 2

$\mathrm{H}_{2} \mathrm{O}_{2}$ (A) and NO (B) production from peritoneal macrophages stimulated with $280 \mu \mathrm{g} / \mathrm{ml} \mathrm{MeOH}(\mathrm{I})$ and 200 $\mu \mathrm{g} / \mathrm{ml} \mathrm{CHCl}$ (2) extracts. Macrophages were exposed to Byrsonima crassa extracts for $\mathrm{I} \mathrm{h}(\mathrm{A})$ and $24 \mathrm{~h}(\mathrm{~B})$. The results are the mean $\pm S D$ of at least three independents experiments carried out in triplicate. $* P<0.05$, significantly different from control without stimulating (negative control). 
secondary metabolites with anti-H. pylori activity. Probably, the antimicrobial activity demonstrated by extracts may be due to the presence of polyphenolic compounds, such as flavonoids, tannins, and terpenoids described in the phytochemical profile of $B$. crassa $[16,32,33]$, not discarding the possibility of a synergistic effects between substances.

H. pylori infection has been associated with generation of oxygen (ROS) and nitrogen (RNS) reactive species, which leads to oxidative stress in gastric mucosa [22,34,35]. This bacterium induces infiltration and activation of phagocytes, which produce inflammatory mediators, cytokines, ROS and RNS. To avoid the negative effects of ROS, $H$. pylori, like many other bacteria, produces enzymes involved in ROS scavenging, such as catalase and superoxide dismutase. H. pylori also activates inducible nitric oxide synthase in the gastric mucosa, which is associated with epithelial cell injury and apoptosis [2]. No evidence was found for a role of free radicals in the pathogenesis of gastric mucosal injury in cases unrelated to $H$. pylori infection [35].

Macrophages are widely distributed in different tissues and play an essential role in the development of the specific and nonspecific immune response. These cells can be activated by a variety of stimuli as bacterial components, cytokines and chemicals. Once activated, macrophages produce and release numerous secretors products including several cytokines, inorganic reactive radicals, reactive oxygen intermediates (ROI) and reactive nitrogen intermediates (RNI) with biological activities [36]. Hydrogen peroxide $\left(\mathrm{H}_{2} \mathrm{O}_{2}\right)$ and nitric oxide (NO) are important in cell signaling and they are effectors molecules for microbicidal and cytotoxic response of macrophages after stimulation [37]. If ROI and RNI may be considered as beneficial intermediates (with respect to its microbicidal and tumoricidal activities), it also can become destructive for the host tissue in certain conditions [38]. NO and reactive oxygen species affect virtually every step of the development of inflammation.

The immunomodulatory activity of several plants compounds has already been described [39]. Davilla elliptica chloroform extract triggered the production of $\mathrm{H}_{2} \mathrm{O}_{2}, \mathrm{NO}$ and tumor necrosis factor-alpha in a dose-dependent manner into cultured macrophages [40] whereas inhibitory effects in $\mathrm{H} 2 \mathrm{O} 2$ and NO production by ethyl acetate fraction from Alchornea glandulosa were demonstrated [41]. In particular, those plants that reduce the formation of NO may be beneficial in pathophysiological conditions where excessive production of NO is a contributory factor.

In this study, we demonstrated that extracts of $B$. crassa induced the production $\mathrm{H}_{2} \mathrm{O}_{2}$ and NO. Agents that reduce the formation of NO may be beneficial in $H$. pylori infections since an excessive production of $\mathrm{NO}$ is an agravating factor in this condition. Finally, increased production of free radicals has been demonstrated to occur during the gastrointestinal metabolism of xenobiotics, which may lead to intestinal disorders [42].

Despite of the antiulcerogenic effect exhibited by $B$. crass $a$ associated with $\mathrm{HCl} /$ ethanol induced gastric ulcers [16] and inhibitory activity against $H$. pylori, an immunostimulatory effect on the liberation of $\mathrm{H}_{2} \mathrm{O}_{2}$ and $\mathrm{NO}$ by $B$. crassa leaves was demonstrated. Based in these results, $B$. crassa can be considered a source of compounds with antiH. pylori activity, but its use should be done with caution in treatment of the gastritis and peptic ulcers, since the reactive oxygen/nitrogen intermediates are involved in the pathogenesis of gastric mucosal injury induced ulcerogenic agents and $H$. pylori infections.

\section{Competing interests}

The authors declare that they have no competing interests.

\section{Authors' contributions}

MS and WV have been involved in the obtaining the extracts. IZC performed the immunological assays. CB and MSGR carried out the cell viability, antimicrobial experiments and preparation of the manuscript. All authors read and approved the final manuscript.

\section{Acknowledgements}

We thank the Fundação de Amparo a Pesquisa do Estado de São Paulo (FAPESP) and to Conselho Nacional de Desenvolvimento Científico e Tecnológico (CAPES) by financial support.

\section{References}

I. Stege PW, Davicino RC, Veja AE, Casali YA, Correa S, Micalizzi B: Antimicrobial activity of aqueous extracts of Larrea divaricata Cav (jarilla) against Helicobacter pylori. Phytomedicine 2006, 13:724-727.

2. Baldari CT, Lanzavecchia A, Telford JL: Immune subversion by Helicobacter pylori. Trends Immunol 2005, 26: 199-207.

3. Matthews GM, Butler RN: Cellular mucosal defense during Helicobacter pylori infection: a review of the role of glutathione and oxidative pentose pathway. Helicobacter 2005, 10:298-306.

4. Montecucco C, Rappuoli R: Living dangerously: how Helicobacter pylori survive in the human stomach. Nat Rev Mol Cell Biol 200I, 2:457-466.

5. Howden CW, Hunt RH: Guidelines for the management of Helicobacter pylori infection. Am J Gastroenterol 1998, 93:2330-2338.

6. Hoffman JS: Pharmacological therapy of Helicobacter pylori infection. Semin Gastrointest Dis 1997, 8:156-163.

7. Glupczynski Y: Antimicrobial resistance in Helicobacter pylori: a global overview. Acta Gastro-Ent Belg 1998, 61:357-366.

8. Babincová M, Schronerová K, Sourivong P: Antiulcer activity of water extract of Scoparia dulcis. Fitoterapia 2008, 79:587-588.

9. Falcão HS, Mariath IR, Diniz MF, Batista LM, Barbosa-Filho JM: Plants of the American continent with antiulcer activity. Phytomedicine 2008, I5: 132-46.

10. Hiruma-Lima CA, Calvo TR, Rodrigues CM, Andrade FD, Souza-Brito ARM: Antiulcerogenic activity of Alchornea castaneaefolia: effects on somatostatin, gastrin and prostaglandin. J Ethnopharmacol 2006, 104:215-224. 
II. Ishikawa T, Donatini RS, Diaz IE, Yoshida M, Bacchi EM, Kato ET: Evaluation of gastroprotective activity of Plinia edulis (Vell.) Sobral (Myrtaceae) leaves in rats. J Ethnopharmacol 2008, I I 8:527-529.

12. Martínez-Vásquez M, González-Esquinca AR, Luna LC, Moreno Gutiérrez MN, Garcia-Argáez AN: Antimicrobial activity of Byrsonima crassifolia (L.) H.B.K. J Ethnopharmacol 1999, 66:79-82.

13. Sannomiya M, Cardoso CRP, Figueiredo ME, Rodrigues CM, dos Santos LC, dos Santos FV, Serpeloni JM, Cólus IMS, Vilegas W, Varanda EA: Mutagenic evaluation and chemical investigation of Byrsonima intermedia A. Juss. leaf extracts. J Ethnopharmacol 2007, I 1 2:319-326.

14. Joly AB: Botânica: Introdução à Taxonomia Vegetal. Companhia Ed Nacional, São Paulo; 1998:808.

15. Silva SR, Silva AP, Munhoz CB, Silva MC Jr, Medeiros MB: Guia de Plantas do Cerrado utilizadas na Chapada dos Veadeiros. Prática Gráfica e Editora Ltda, Brasília; 200 I:I 32.

16. Sannomiya M, Fonseca VB, da Silva MA, Rocha LR, dos Santos LC, Hiruma-Lima CA, Souza-Brito ARM, Vilegas W: Flavonoids and antiulcerogenic activity from Byrsonima crassa leaves extracts. J Ethnopharmacol 2005, 97: I-6.

17. Iwai $\mathrm{K}$, Onodera $\mathrm{A}$, Matsue $\mathrm{H}$ : Antioxidant activity and inhibitory effect of Gamazumi (Viburnum dilatatum Thumb.) on oxidative damage induced by water immersion restraint stress in rat. Int J Food Sci Nutr 200I, 52:443-45I.

18. Funatogawa K, Hayashi S, Shimomura H, Yoshida T, Hatano T, Ito $\mathrm{H}$ Hirai Y: Antibacterial activity of hydrolyzable tannins derived from medicinal plants against Helicobacter pylori. Microbiol Immunol 2004, 48:25I-26I.

19. Menghini L, Epifano F, Leporini L, Pagiotti R, Tirillini B: Phytochemical investigation on leaf extract of Cordia salicifolia Cham. Med Food 2008, II:193-194.

20. Ndipa RN, Tarkanga AEM, Mbullaha SM, Lumab HN, Malongueb A Ndipa LN, Nyongbelac K, Wirmumd C, Efangec SMN: In vitro antiHelicobacter pylori activity of extracts of selected medicinal plants from North West Cameroon. J Ethnopharmacol 2007, I I 4:452-7.

21. Shikov AN, Pozharitskaya ON, Makarov VG, Kvetnaya AS: Antibacterial activity of Chamomilla recutita oil extract against Helicobacter pylori. Phytother Res 2008, 22:252-253.

22. Arend A, Loime L, Roosaar P, Soom M, Lõivukene K, Sepp E, Aunapuu M, Zilmer K, Selstam G, Zilmer M: Helicobacter pylori substantially increases oxidative stress in indomethacin-exposed rat gastric mucosa. Medicina (Kaunas) 2005, 41:343-347.

23. Bagchi D, McGinn TR, Ye X, Bagchi M, Krohn RL, Chatterjee A, Stohs SJ: Helicobacter pylori-induced oxidative stress and DNA damage in a primary culture of human gastric mucosal cells. Dig Dis Sci 2002, 47: | 405-1412

24. Ernst P: Review article: the role of inflammation in the pathogenesis of gastric cancer. Aliment Pharmacol Ther 1999, 13:13-18.

25. Eloff JN: Which extractant should be used for the screening and isolation of antimicrobial components from plants. J Ethnopharmacol 1998, 60:1-8.

26. Borenfreund $E$, Puerner JA: Toxicity determined in vitro by morphological alterations and neutral red absorption. Toxicol Lett 1985, 24:119-124.

27. Pick $E$, Mizel $D$ : Rapid microassays for the measurement of superoxide and hydrogen peroxide production by macrophages in culture using an automatic enzyme immunoassay reader. J Immunol Methods 198I, 46:2I I-226.

28. Green LC, Wagner DA, Glogorwki J, Skipper PL, Wisnok JS, Tannenbowm SR: Analysis of nitrate, nitrite and (I5N) nitrate in biological fluids. Anal Biochem 1982, I 26:131-138.

29. Fukai T, Marumo A, Kaitou K, Kanda T, Tereda S, Nomura T: AntiHelicobacter pylori flavonoids from licorice extract. Life Sci 2002, 71 : | 1449-1 463

30. Nostro A, Cellini L, Di Bartolomeo S, Di Campli E, Grande R, Cannatelli MA, Marzio L, Alonzo V: Antibacterial effect of plants extracts against Helicobacter pylori. Phytother Res 2005, 19:198-202.

3I. Shin JE, Kim JM, Bae EA, Hyun YJ, Kim DH: In vitro inhibitory effect of flavonoids on growth, infection and vacuolation of Helicobacter pylori. Planta Med 2005, 71:197-20I.

32. Arantes VP, Sato DN, Vilegas W, Santos LC, Leite CQF: Plantas do cerrado brasileiro com atividade contra Mycobacterium fortuitum. Rev Ciênc Farm Básica Apl 2005, 26:195-198.

33. Cardoso CR, de Syllos Cólus IM, Bernardi CC, Sannomiya M, Vilegas W, Varanda EA: Mutagenic activity promoted by amentoflavone and methanolic extract of Byrsonima crassa Niedenzu. Toxicol 2006, 225:55-63.

34. Allen LH, Beecher BR, Lynch JT, Rohner V, Wittine LM: Helicobacter pylori disrupts NADPH oxidase targeting in human neutrophils to induce extracellular superoxide release. Immunol 2005, 174:3658-3667.

35. Davies GR, Simmonds NJ, Rampton DS: Helicobacter pylori stimulates antral mucosal reactive oxygen metabolite production in vivo. Gut 1994, 35:179-185.

36. Forman HJ, Torres M: Redox signaling in macrophages. Mol Aspects Med 200I, 22:189-2I6.

37. Kayser $\mathrm{O}$, Kolodziej $\mathrm{H}$, Kiderlen AF: Immunomodulatory principles of Pelargonium sidoides. Phytother Res 2000, I5:122-126.

38. McBride AG, Borutaité V, Brown GC: Superoxide dismutase and hydrogen peroxide cause rapid nitric oxide breakdown, peroxynitrite production and subsequent cell death. Biochim Biophys Acta 1999, 1454:275-88.

39. Moreira RRD, Carlos IZ, Vilegas W: Release of intermediate reactive hydrogen peroxide by macrophage cells actived by natural products. Biol Pharm Bull 200I, 24:20I-204.

40. Mascia Lopes FC, Polesi Placeres MC, Jordão CM Jr, Higuchi CT, Rinaldo D, Vilegas W, Fujimura Leite CQ, Carlos IZ: Immunological and microbiological activity of Davilla elliptica St. Hill. (Dilleniaceae) against Mycobacterium tuberculosis. Mem Inst Oswaldo Cruz 2007, 102:769-72.

4I. Lopes FCM, Calvo TR, Vilegas W, Carlos IZ: Inhibition of hydrogen peroxide, nitric oxide and TNF-. Alchornea glandulosa 2005 , 28:1726-1730.

42. Mansbach CM, Rosen GM, Rahn CA, Strauss KE: Detection of free radicals as a consequence of rat intestinal cellular drug metabolism. Biochim Biophys Acta 1986, 888: I-9.

\section{Pre-publication history}

The pre-publication history for this paper can be accessed here:

\section{http://www.biomedcentral.com/1472-6882/9/2/prepub}

Publish with Bio Med Central and every scientist can read your work free of charge

"BioMed Central will be the most significant development for disseminating the results of biomedical research in our lifetime. "

Sir Paul Nurse, Cancer Research UK

Your research papers will be:

- available free of charge to the entire biomedical community

- peer reviewed and published immediately upon acceptance

- cited in PubMed and archived on PubMed Central

- yours - you keep the copyright
BioMedcentral 